\title{
Volcanology at DGGS
}

Alaska Division of Geological \& Geophysical Surveys

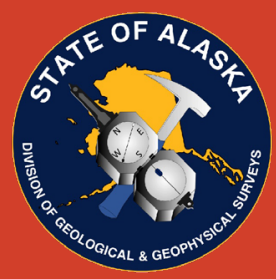

Alaska is home to more than 100 volcanoes. 54 are considered historically active and on average 1 or 2 erupt every year. Eruptions in Alaska impact air commerce, economic well-being, infrastructure, and lives.

\section{Alaska Volcano Observatory}

The volcanology section at the Alaska Division of Geological \& Geophysical Surveys (DGGS) is a partner in the interagency Alaska Volcano Observatory (AVO), a federally funded program that researches and evaluates volcano-related hazards in Alaska in order to reduce their impacts. As a partner in AVO, DGGS' Volcanology Section participates in volcano monitoring, eruption response, geologic mapping, hazard communication, database and website development and design, and geologic sample archiving.

\section{Volcano Monitoring \&} Eruption Response

DGGS-AVO staff participate in around-the-clock volcano monitoring using satellite and seismic data to assess activity levels at volcanoes. Detailed records of eruption timelines, pilot reports, and monitoring data are kept to help make informed decisions before, during, and after a volcanic event. DGGS-AVO keeps the public informed through the

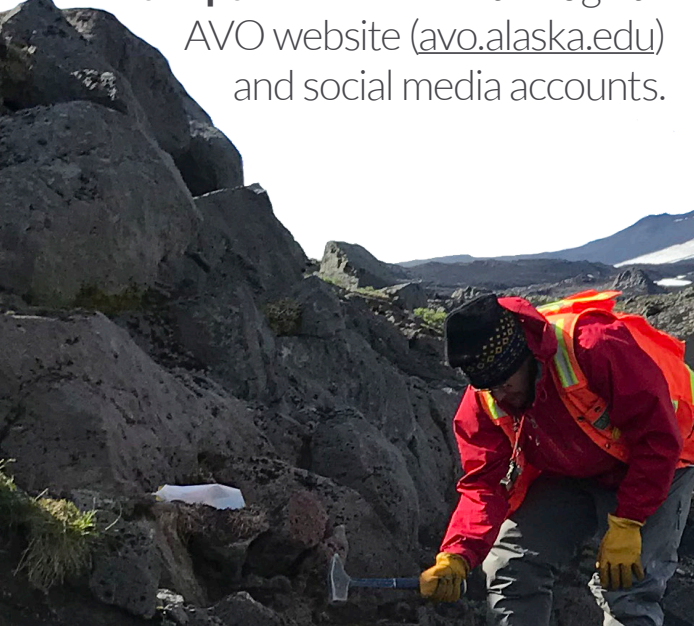

USGS/AVO geologist Matt Loewen côllects geologic samples at Shishaldin volcano, as part of a DGGS-led mapping project.

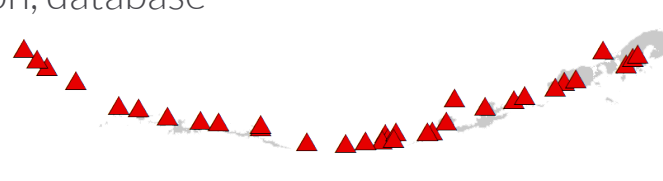

Geologic \& Hazard Assessment Mapping

The volcanologists at DGGS-AVO strive to understand the nature, timing, and likelihood of volcanic activity by conducting geologic studies. These studies improve our understanding of Alaska's volcanoes and help forecast future eruptions and their potential impact on society.
The work done by DGGS-AVO helps the State respond more efficiently and effectively before, during, and after $a$ volcanic event.
Historically active volcanoes in Alaska 


\section{Volcanology}

Alaska Division of Geological \& Geophysical Surveys

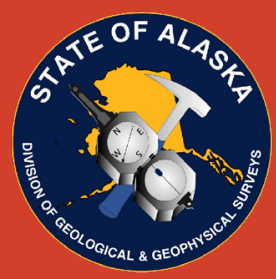

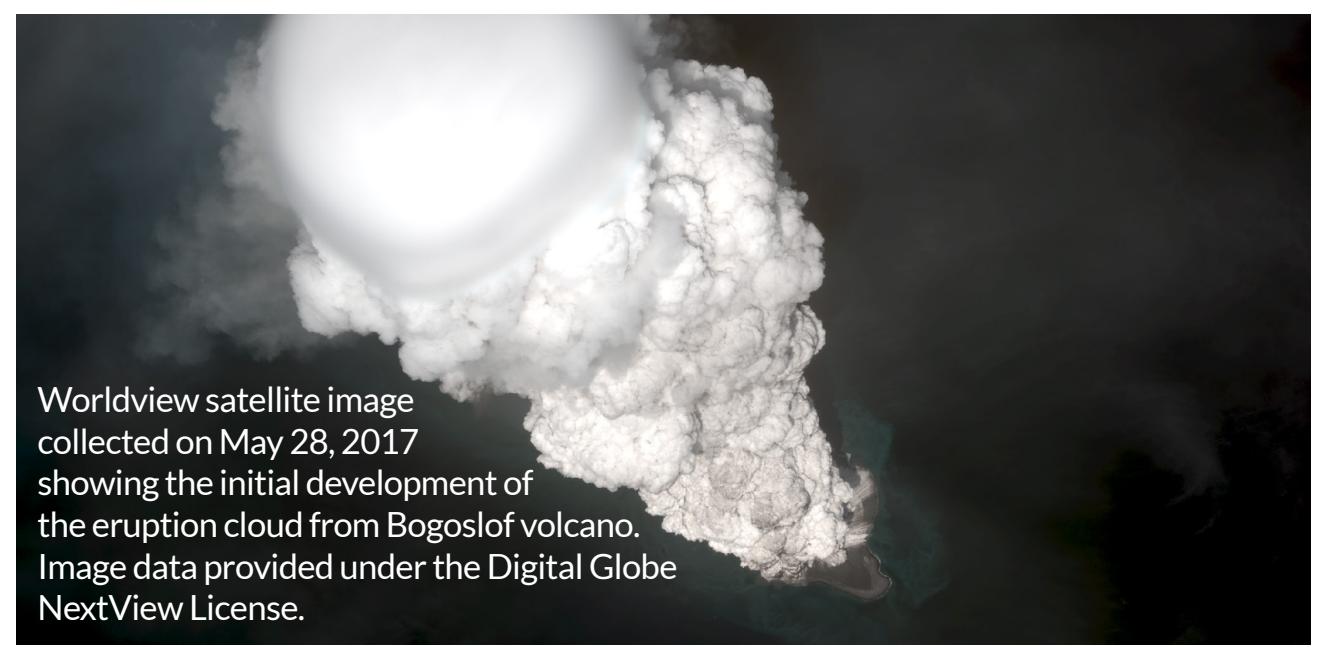

Eruption Response: A Case Study

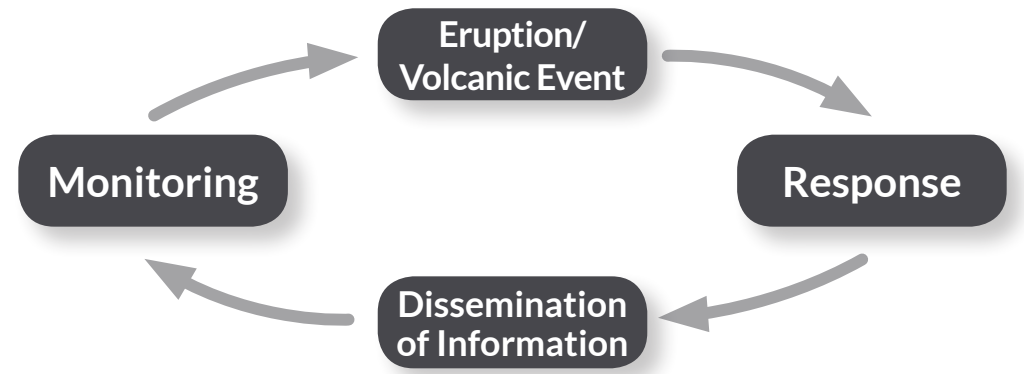

From late 2016 through most of 2017, Bogoslof volcano erupted more than 60 times. Bogoslof is a small island located approximately 60 miles $(100 \mathrm{~km})$ from Dutch Harbor. The eruptions resulted in trace ash fall on Unalaska and numerous flight cancellations. In addition to normal eruption response activities (monitoring and keeping the public informed), DGGS-AVO staff developed an internal chat server to enable efficient internal communication between AVO scientists. This chat server allows for more rapid volcano alerts and information to reach the public. Recently, it was used by the Hawaiian Volcano Observatory during the 2018 eruption of Kîlauea Volcano and became a crucial tool to eruption response efforts there.

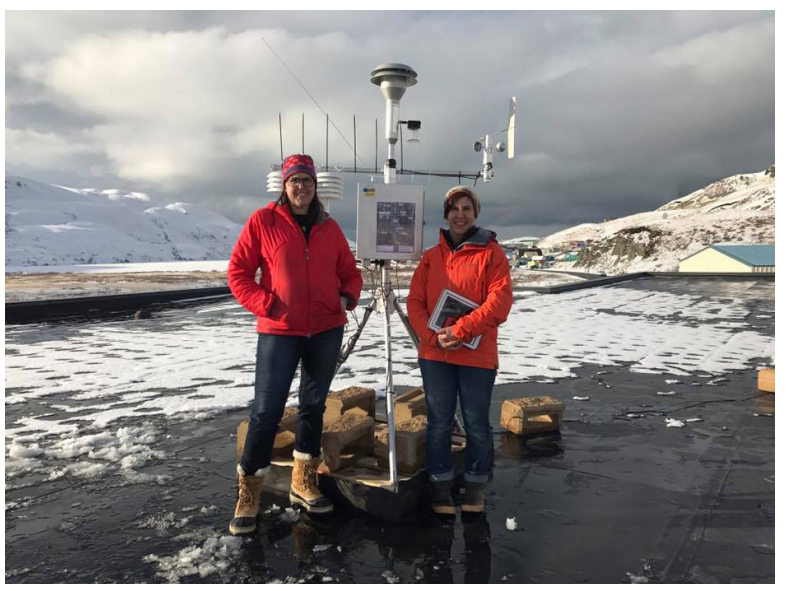

\section{Database, Website, and Archiving}

The Volcanology Section at DGGS developed and maintains the Geologic Database of Information on Volcanoes in Alaska (GeoDIVA), a

comprehensive and up-to-date source of information on volcanoes in Alaska. The data housed in GeoDIVA support scientific investigation, crisis response, and is the heart of AVO's database-driven public website (avo.alaska.edu).

\section{Website Data}

\section{The AVO website and database stores:}

\section{More than 27,000 images \\ More than 17,000 geologic samples}

\section{More than 10,500 \\ geochemistry samples}

\section{5,000 bibliographic references}

The website is a valuable public and scientific resource, providing basic volcano information along with details of the last $\sim 2.6$ million years of volcanic activity in Alaska. www.avo.alaska.edu

Learn more online: dggs.alaska.gov or contact Janet Schaefer janet.schaefer@alaska.gov 907-451-5005

\footnotetext{
- Bogoslof volcano
}

AVO geologists Janet Schaefer and Kristi Wallace visit Unalaska and Dutch Harbor to meet with the community and talk about ashfall from the Bogoslof eruption and install an air quality monitoring instrument. alaska.avo @alaska_avo 